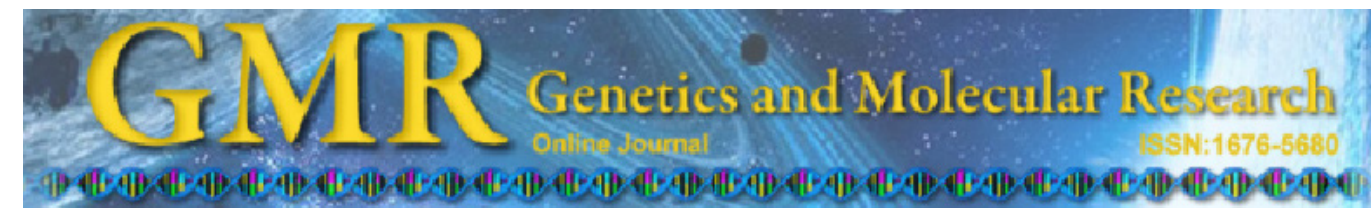

\title{
Phenotypic and genotypic variation among Capsicum annuum recombinant inbred lines resistant to bacterial spot
}

\author{
S.O. Moreira ${ }^{1}$, R. Rodrigues ${ }^{2}$, H.S. Oliveira ${ }^{2}$, A.M. Medeiros ${ }^{2}$, C.P. Sudré ${ }^{2}$ \\ and L.S.A. Gonçalves ${ }^{3}$ \\ ${ }^{1}$ Instituto Capixaba de Pesquisa, Assistência Técnica e Extensão Rural, \\ Estação Experimental de Linhares, Linhares, ES, Brasil \\ ${ }^{2}$ Universidade Estadual do Norte Fluminense Darcy Ribeiro, \\ Campos dos Goytacazes, RJ, Brasil \\ ${ }^{3}$ Universidade Estadual de Londrina, Centro de Ciências Agrárias, \\ Londrina, PR, Brasil \\ Corresponding author: R. Rodrigues \\ E-mail: rosana@uenf.br
}

Genet. Mol. Res. 12 (2): 1232-1242 (2013)

Received July 30, 2012

Accepted January 12, 2013

Published April 17, 2013

DOI http://dx.doi.org/10.4238/2013.April.17.2

\begin{abstract}
A breeding program carried out under Brazilian growing conditions to obtain Capsicum annuum cultivars with disease resistance to bacterial spot (BS) produced 8 promising recombinant inbred lines (RILs). The present study aimed to characterize these RILs using phenotypic descriptors and molecular markers (inter-simple sequence repeat) and to confirm their resistance to BS. Twenty-two phenotypic descriptors and 15 inter-simple sequence repeat primers were used to characterize the RILs. The parent, UENF 1381, which is resistant to BS, and 'Casca Dura Ikeda', a traditional cultivar, were used as standards. Variability among genotypes was observed considering either binary or multicategorical characteristics, such as fruit length, fruit diameter, and fruit longitudinal and transversal section. Such variability in fruit traits can be exploited to develop new genotypes with BS resistance for various types of market consumption. RILs numbered 1, 3, and 6 were the most homogenous, whereas those coded 2, 5, 8, and 11 had the same
\end{abstract}


level of heterogeneity as that observed in 'Casca Dura Ikeda'. Molecular analysis clustered the genotypes into 5 groups, with RILs 1, 2, 3, and 5 allocated in isolated groups. RILs 1, 2, 6, and 8 confirmed resistance to BS. Considering homogeneity level and BS resistance, RILs 1 and 6 were suitable for use as pre-cultivars in final tests to register and release two new C. annuum cultivars.

Key words: Phenotypic descriptors; ISSR markers; Genetic disease resistance; Sweet and chili pepper

\section{INTRODUCTION}

The genus Capsicum, which includes sweet and chili peppers, has great economic importance for integrating small, medium, and large companies in their cultivation and processing, increasing their capacities to generate employment and income (Costa et al., 2009; Moura et al., 2010; Sudré et al., 2010). However, diseases such as bacterial spot (BS), caused by Xanthomonas spp, are responsible for significant losses in fruit quality and yield in these crops (Macuzzo et al., 2009; Hamza et al., 2010). The use of resistant cultivars is one of the most effective methods for controlling BS because chemicals are inefficient and can lead to resistant pathogens. Several resistance genes have already been found and described for BS (Sowell Jr., 1960; Cook and Guevara, 1984; Jones et al., 2002; Riva-Souza et al., 2004). Recently, the $B s 7$ gene has been identified, characterized, and introgressed from Capsicum baccatum to $C$. annuит, generating a near-isogenic line named ECW70R (Potnis et al., 2012).

In Brazil, the Universidade Estadual do Norte Fluminense Darcy Ribeiro (UENF) has developed a $C$. annuum breeding program aiming to obtain cultivars with resistance to BS. In this program, 18 promising recombined inbred lines (RILs) for resistance and yield were obtained from bi-parental crosses between accessions UENF 1421 (sweet pepper, susceptible to BS) and UENF 1381 (chili pepper, resistant to BS) using the single-seed descent breeding method (RivaSouza et al., 2009). These RILs have been tested under various environmental conditions to identify superior lines for specific crop management systems (Moreira et al., 2009, 2010).

Along with disease resistance and yield, phenotypic characteristics such as fruit shape, fruit color, and fruit size associated with these RILs have been evaluated and these must achieve a quality level that meets the expectations of farmers and consumers. These aspects should be observed consistently in developing cultivars using the list of descriptors, how as developed by Brasil (2006). These phenotypic descriptors should be evaluated at various stages of plant development and are capable of identifying characteristics of economic interest. However, such descriptors have limitations such as subjectivity during evaluation and the time necessary to perform them, because many of them are observed in adult plants. In addition, these variables may be insufficient for distinguishing cultivars that have the same genealogy, as in the case of RIL (Priolli et al., 2002).

The use of molecular markers is a powerful approach to the characterization of various genotypes because it can show differences at the DNA level, which is unaffected by plant growth stage, local conditions, planting time, or agronomic management (Kwon et al., 2005). Molecular techniques have been used successfully to differentiate cultivars, including those requiring intellectual property protection (Goulão and Oliveira, 2001; Reddy et al., 2002; Shen 
et al., 2006). Among molecular markers, inter-simple sequence repeats (ISSR) are based on variations in the regions between microsatellites. This genotyping technique has a wide range of uses, including the characterization of genetic relatedness among populations, genetic fingerprinting, detection of clonal variation, and cultivar identification. The technique is considered as simple and fast as the random amplified polymorphic DNA technique but with greater stringency (Reddy et al., 2002). The present study aimed to characterize the 8 RILs obtained in the UENF C. annuum breeding program using phenotypic descriptors and ISSR markers to confirm the genetic resistance to BS and establish a protocol for distinguishing recombinant lines.

\section{MATERIAL AND METHODS}

Eight pre-selected RILs identified as 1, 2, 3, 5, 6, 8, 11, and 13 in preliminary studies (Moreira et al., 2009, 2010) were tested. These lines corresponded to the $\mathrm{F}_{7}$ generation from crosses between the accessions UENF 1421 and UENF 1381. The accession UENF 1421 is susceptible to BS, with yield and fruit quality that cater to the sweet pepper market, whereas UENF 1381 is a chili pepper accession that has been used as a source of BS resistance in the UENF breeding program. Along with the RILs, UENF 1381 and the sweet pepper cultivar 'Casca Dura Ikeda' were evaluated.

The field experiment was carried out from August to December 2010 at Estação Experimental de Campos located in Campos dos Goytacazes, Rio de Janeiro, Brazil (latitude $21^{\circ} 19^{\prime} 23^{\prime \prime S}$ and longitude $41^{\circ} 19^{\prime} 40^{\prime \prime} \mathrm{W}$, altitude $13 \mathrm{~m}$ ). A complete randomized block design was used with three replications and 18 plants per plot, with 12 useful plants per plot.

Twenty-two descriptors were used to evaluate and distinguish the RILs from each other and from standard genotypes. Twenty-one phenotypic descriptors were chosen from among those suggested by Serviço Nacional de Proteção de Cultivares (SNPC) to perform the tests required for Capsicum cultivar protection (Brasil, 2006). These descriptors were used because they presented greater variability among the RILs studied (Table 1). To evaluate these descriptors, we performed a side-by-side comparison in which characteristics were visually observed and a corresponding rate was conferred for each genotype using the scale presented in Table 1. This approach is recommended for trials with very similar cultivars when testing clonally propagated species or autogamous plants in which relatively little variation occurs between plants of the cultivar (Brasil, 2011). The descriptors were observed in fully developed leaves on lateral branches after the first bifurcation during flowering. When fruit descriptor observation was carried out, the fruits were ripe and originating from a second or third node.

For the reaction to BS, an experiment was conducted under controlled conditions in a greenhouse at Unidade de Apoio à Pesquisa on the UENF campus using a completely randomized design with 10 replicates and 1 plant per plot. The inoculum production and artificial inoculation were performed as described by Riva-Souza et al. (2009). The analysis of the reaction to BS was performed from the 5th day after inoculation by means of 7 observations at intervals of $24 \mathrm{~h}$, giving the following scores for symptoms at the inoculation site: 1 , no visible symptoms; 2 , inoculated area with chlorosis; 3 , yellow inoculated area with a few spots of necrosis; 4 , necrotic spots in inoculated area; 5 , inoculated area completely necrotic. The score for each genotype corresponded to the modal value among all the plants that were evaluated after the 7 th observation. Plants with a score of 2 or less were considered to be resistant, and those that scored above 2 were considered to be susceptible (Riva-Souza, 2006). 
Table 1. Twenty-one phenotypic descriptors used to characterize 8 recombinant inbred lines of Capsicum annuum L. and 2 standard genotypes (UENF 1381) and 'Casca Dura Ikeda'.

\begin{tabular}{ll}
\hline Plant organ & Characteristic description \\
\hline Leaf & Length: short (3), average (5), long (7) \\
& Width: narrow (3), medium (5), large (7) \\
& Green color: clear (3), middle (5), dark (7) \\
& Pubescence: absent (1), sparse (3), middle (5), dense (7) \\
& Roughness: absent (1), weak (3), middle (5), strong (7) \\
& Position: erect (1), intermediate (3), pendant (5) \\
& Position of stigma: insert (3), the same level (5), exerted (7) \\
Flower & Size: short (3), medium (5), long (7) \\
& Thickness: thin (3), medium (5), thick (7) \\
Peduncle & Size: small (3), medium (5), large (7) \\
& Intensity of color before maturity: clear (3), middle (5), dark (7) \\
Placenta & Length: very short (1), short (3), medium (5), long (7), very long (9) \\
Fruit & Diameter: very small (1), small (3), medium (5), large (7), very large (9) \\
& Predominant shape in longitudinal section: flat (1), round (2), heart (3), square (4), rectangular (5), \\
& trapezoidal (6), triangular (7), narrow-triangular (8), horn (9), oval (10), elliptical (11) \\
& Predominant shape of the transversal section: elliptical (1), angled (2), rounded (3) \\
& Surface texture: smooth (1), slightly wrinkled (2), strongly corrugated (3) \\
& Depth of the depression: absent or very shallow (1), shallow (3), means (5), deep (7), too deep (9) \\
& Shape of apex: acute (3), rounded (5), depressed (7) \\
& Depth of the interlocular grooves: absent or very shallow (1), shallow (3), means (5), deep (7), too deep (9) \\
& Pericarp thickness: thin (3), middle (5), thick (7) \\
& Capsaicin: absent (1), present (2) \\
\hline
\end{tabular}

Any plant that could clearly be distinguished from others in the same RIL was considered atypical, and this criterion was used to verify the homogeneity of the lines. Per SNPC (Brasil, 2006), 2 was the maximum number of phenotypically distinct individuals that could exist within one RIL to consider a studied genotype homogeneous according to the descriptors used.

Molecular analysis using ISSR was conducted at Laboratório de Melhoramento Genético Vegetal of UENF. DNA extraction was performed in young leaf tissue collected from the same plants obtained for evaluating resistance to BS before inoculation. Leaves from 10 plants of each genotype were harvested in bulk. Approximately $50 \mathrm{mg}$ macerated tissue was transferred to 1.5$\mathrm{mL}$ tubes and immersed in liquid nitrogen for DNA extraction, which was performed with a Plant Genomic DNA Mini Kit (Kit YGP100) according to manufacturer instructions.

DNA concentration was determined using a Pico100 spectrophotometer (Picodrop Microliter UV/Vis Spectrophotometer with UVpette Tips), the absorbance was measured at wavelengths of 260 and $280 \mathrm{~nm}$, and the purity of DNA samples was analyzed according to the $\mathrm{A}_{260} / \mathrm{A}_{280}$ ratio. Concentration was determined using 2- $\mu \mathrm{L}$ samples that were preserved for further use. In addition, samples were examined on $1.0 \%$ agarose gel and stained with a mixture of 6X Juice Blue and 0.002X Gel Red in a 1:1 ratio. The gel was visualized with ultraviolet light (MiniBIS Pro, Bio-Imaging Systems).

To improve the purity, we centrifuged the DNA again at 13,000 $\mathrm{g}$ for $5 \mathrm{~min}$ and the pelleted impurities were eliminated. The purified DNA was then diluted 10-fold and rinsed with RNase to obtain the final working solution.

Preliminarily, 47 ISSR primers were tested using 3 genotypes. Of these 47 primers, the following 15 were selected owing to their greater polymorphism: (CAC) 3GC; (AG) 8YT; (GA) 8C, (CT) 8G; (AC) 8T; (AG) 8YC; (AG) 8YA; (GA) 8YT; (CA) 8RG; (GT) 8YC; (ATG) 6; VHV (GT) 7; (ATC) 6T; [G (CTA)] 6; (AG) 7C.

The amplification reactions were completed in a final volume of $13 \mu \mathrm{L}$ containing 
the following reagents: $6.1 \mathrm{~mL}$ ultrapure water; $1.5 \mathrm{~mL} 10 \mathrm{X}$ buffer; $0.78 \mathrm{~mL} 25 \mathrm{mM} \mathrm{MgCl}$; $1.5 \mathrm{~mL} 2 \mathrm{mM}$ deoxyribonucleotide triphosphate; $1.0 \mathrm{~mL} 5 \mu \mathrm{M}$ primers; and $0.12 \mathrm{U}$ Taq DNA polymerase. This mixture was applied to $2 \mu \mathrm{L}$ DNA at $0.5 \mathrm{ng} / \mu \mathrm{L}$. The amplified fragments were separated on $2.0 \%$ agarose gel stained with a mixture of $6 \mathrm{X}$ Juice Blue and $0.002 \mathrm{X}$ Gel Red (1:1) and visualized with ultraviolet light (MiniBIS Pro). The gel images were captured for later analysis.

From bands generated with each primer, a binary matrix was constructed that was used to calculate the dissimilarity matrix using the arithmetic complement of the Jaccard index. For clustering analysis, we used the unweighted pair group with arithmetic mean (UPGMA) and Tocher methods. The clusters were validated using the cophenetic correlation coefficient (Sokal and Rohlf, 1962). The resolving power of the primers was calculated according to methodology proposed by Prevost and Wilkinson (1999). Statistical analyses were performed using the R program (R Development Core Team, 2006) with the exception of the Tocher method, which was obtained using the Genes program (Cruz, 2006).

\section{RESULTS AND DISCUSSION}

During the field experiment, temperatures ranged from $16.6^{\circ}$ to $32.7^{\circ} \mathrm{C}$ and were favorable for BS occurrence (Marcuzzo et al., 2009). However, no disease symptoms corresponding to BS were observed in plants, and therefore evaluation of resistance to a natural occurrence of the pathogen was not carried out.

Significant differences were observed among the genotypes studied. However, for a cultivar to be considered distinct from the others, the differences between them must be clear. Determining such a difference between two cultivars depends on several factors and, in particular, the type of expression of the trait must be considered (Brasil, 2011).

Binary characteristics are those in which descriptors can be classified on two levels, and two genotypes should not be considered distinct if both are at the same level of expression. Only the descriptor presence of capsaicin in the placenta matched this criterion. Capsaicin was observed in fruits from RILs 3, 5, 8, 11, and 13, as well as in parent UENF 1381. In RILs 1, 2 , and 6 and the cultivar 'Casca Dura Ikeda', capsaicin was absent (Table 2). These data agree with those obtained by Moreira (2008). Capsaicin, an alkaloid that confers pungency in the fruits of some Capsicum spp, is produced in the placenta and released when the fruit is physically damaged (Moreira et al., 2006). The presence and amount of capsaicin in chili pepper cultivars used for culinary purposes differ, and to satisfy the consumer market, cultivars with different levels of pungency must be obtained. The presence of capsaicin should be one of the main characteristics evaluated by Capsicum breeders (Lee et al., 2005).

Multicategorical characteristics are descriptors that have more than two levels of expression. When a multicategorical descriptor is distributed on a scale, a single level of expression may be insufficient to differentiate between recombinant lines. Thus, for these descriptors, the lines were considered distinct if they were more than two levels apart. Differences could be observed among genotypes in all multicategorical descriptors (see Table 2). However, according to the determinations of the SNPC (Brasil, 2011), these differences were considered clear enough to discriminate the RILs for only 12 multicategorical descriptors.

The descriptor length of leaf discriminated the parent UENF 1381 from RIL 1 and 'Casca Dura Ikeda'. Leaf pubescence distinguished RIL 1 (which is hairy) from RILs 5, 8, and 
13 and 'Casca Dura Ikeda', which lack pubescence. The position of the stigma allowed the differentiation of RILs 2, 6, and 11 from RILs 1, 5, 8, and UENF 1381. RIL 13 was considered different from RIL 6 and 'Casca Dura Ikeda' with respect to the intensity of fruit color before maturation. 'Casca Dura Ikeda' was the only genotype with large fruit diameter. 'Casca Dura Ikeda' was also distinguished from other genotypes by its deep peduncular depression and depressed shape of fruit apex. Along with RIL 11, the commercial genotype was also distinguished by having medium-depth interlocular grooves.

\begin{tabular}{|c|c|c|c|c|c|c|c|c|c|c|}
\hline Descriptors & RIL 1 & RIL 2 & RIL 3 & RIL 5 & RIL 6 & RIL 8 & RIL11 & RIL13 & $\begin{array}{c}\text { UENF } \\
1381\end{array}$ & $\begin{array}{l}\text { 'Casca Dura } \\
\text { Ikeda' }\end{array}$ \\
\hline \multicolumn{11}{|l|}{ Leaf } \\
\hline Length & $7(0)$ & $5(0)$ & $5(0)$ & $5(23)$ & $5(0)$ & $5(0)$ & $5(0)$ & $5(0)$ & $3(0)$ & $7(0)$ \\
\hline Width & $5(0)$ & $3(0)$ & $3(0)$ & $3(0)$ & $3(0)$ & $3(0)$ & $5(0)$ & $3(0)$ & $3(0)$ & $5(0)$ \\
\hline Green color & $7(0)$ & $5(0)$ & $7(0)$ & $7(0)$ & $5(0)$ & $5(0)$ & $5(0)$ & $5(0)$ & $5(0)$ & $7(0)$ \\
\hline Pubescence & $5(0)$ & $3(0)$ & $3(0)$ & $1(0)$ & $3(0)$ & $1(0)$ & $3(0)$ & $1(0)$ & $3(0)$ & $1(0)$ \\
\hline Roughness & $3(0)$ & $1(2)$ & $1(0)$ & $1(0)$ & $3(0)$ & $1(0)$ & $3(0)$ & $3(0)$ & $1(0)$ & $1(0)$ \\
\hline \multicolumn{11}{|l|}{ Flower } \\
\hline Position & $3(2)$ & $3(0)$ & $5(4)$ & $3(2)$ & $3(0)$ & $3(0)$ & $3(0)$ & $3(0)$ & $3(0)$ & $3(0)$ \\
\hline Position of stigma & $3(2)$ & $7(4)$ & $5(7)$ & $3(13)$ & $7(4)$ & $3(3)$ & $7(0)$ & $5(15)$ & $3(5)$ & $5(17)$ \\
\hline \multicolumn{11}{|l|}{ Fruit } \\
\hline Intensity of color before maturity & $5(0)$ & $5(0)$ & $5(0)$ & $5(0)$ & $7(0)$ & $5(0)$ & $5(0)$ & $3(0)$ & $5(0)$ & $7(0)$ \\
\hline Length & $5(0)$ & $3(0)$ & $3(0)$ & $5(0)$ & $3(0)$ & $3(0)$ & $3(0)$ & $3(0)$ & $3(0)$ & $5(0)$ \\
\hline Diameter & $3(0)$ & $3(0)$ & $3(0)$ & $3(0)$ & $3(0)$ & $3(0)$ & $3(0)$ & $3(0)$ & $3(0)$ & $7(0)$ \\
\hline Predominant in longitudinal section & $9(1)$ & $11(0)$ & $11(0)$ & $9(11)$ & $7(23)$ & $10(13)$ & $8(26)$ & $11(0)$ & $11(15)$ & $7(18)$ \\
\hline Predominant form of the cross section & $2(1)$ & $1(11)$ & $2(5)$ & $2(17)$ & $3(13)$ & $2(9)$ & $2(11)$ & $2(0)$ & $3(15)$ & $2(6)$ \\
\hline Surface texture & $2(0)$ & $1(0)$ & $2(12)$ & $2(11)$ & $2(16)$ & $1(9)$ & $2(7)$ & $2(10)$ & $1(14)$ & $1(12)$ \\
\hline Depth of the depression & $5(3)$ & $5(11)$ & $5(4)$ & $5(4)$ & $5(12)$ & $5(13)$ & $7(12)$ & $5(18)$ & $5(9)$ & $5(5)$ \\
\hline Shape of apex & $3(0)$ & $3(0)$ & $3(0)$ & $3(0)$ & $5(0)$ & $5(17)$ & $5(16)$ & $3(13)$ & $5(6)$ & $7(6)$ \\
\hline Depth of the interlocular grooves & $3(20)$ & $1(14)$ & $3(16)$ & $3(12)$ & $1(13)$ & $1(12)$ & $5(21)$ & $1(4)$ & $1(7)$ & $5(19)$ \\
\hline Pericarp thickness & $5(1)$ & $5(4)$ & $5(1)$ & $5(9)$ & $5(1)$ & $5(2)$ & $5(0)$ & $5(4)$ & $5(9)$ & $7(2)$ \\
\hline Capsaicin & $1(1)$ & $1(2)$ & $2(1)$ & $2(2)$ & $1(7)$ & $2(0)$ & $2(1)$ & $2(1)$ & $2(0)$ & $1(1)$ \\
\hline \multicolumn{11}{|l|}{ Placenta } \\
\hline Size & $7(0)$ & $7(0)$ & $7(0)$ & $7(0)$ & $7(0)$ & $7(0)$ & $7(0)$ & $5(9)$ & $7(0)$ & $7(7)$ \\
\hline \multicolumn{11}{|l|}{ Peduncle } \\
\hline Size & $7(0)$ & $5(2)$ & $5(0)$ & $7(0)$ & $5(1)$ & $5(0)$ & $5(0)$ & $5(0)$ & $5(0)$ & $7(2)$ \\
\hline Reaction to bacterial spot & $2(1)$ & $2(0)$ & $5(1)$ & $5(0)$ & $1(1)$ & $1(1)$ & $5(1)$ & $5(2)$ & $2(4)$ & $5(0)$ \\
\hline Heterogeneous descriptor number & 5 & 9 & 7 & 9 & 8 & 9 & 9 & 11 & 13 & 9 \\
\hline
\end{tabular}

$\mathrm{RIL}=$ recombinant inbred line.

No definite scale exists for the descriptors related to fruit shape, for example, its longitudinal and transversal sections. Using these descriptors, we observed the various shapes of fruits among the lines studied: a longitudinal section of fruit ranged from triangular to narrow-triangular (RILs 6 and 11 and 'Casca Dura Ikeda'), horn shaped (RILs 1 and 5), oval (RIL 8), and elliptical (RILs 2, 3, and 13 and parent UENF 1381). RIL 2 was the only genotype with an elliptical transversal fruit section; RIL 6 and UENF 1381 had rounded sections, and the other genotypes studied displayed angular shapes. This diversity of fruit shapes contributes significantly to the sweet and chili pepper markets because it provides alternatives to the producer and the consumer.

With regard to the reaction to BS, we distinguished the lines using criteria suggested by Riva-Souza (2006). Following these criteria, RILs 1, 2, 6, and 8 and parent UENF 1381 were considered distinct and classified as resistant. For the Capsicum breeding program described in this report, this descriptor is the most important for differentiating the RILs because 
thus far, no pure lines of sweet or chili peppers with BS resistance have been protected or registered. Only hybrid cultivars that exploit the BS resistance conferred by the Bs2 gene are registered in Brazil. Because some of the RILs are resistant to BS, using only this descriptor should be enough to differentiate these RILs, which are potential candidates to be released as cultivars, from other genotypes (Brasil, 2006). Nevertheless, homogeneity and stability should also be carefully analyzed in the request for protection of cultivars, and tests of value for cultivation and use should be required to apply for registration of future cultivars.

The RILs were separated into two groups when the descriptor fruit length was considered. The first group was composed by RILs 1 and 5 and 'Casca Dura Ikeda', which produced fruits with average length; the remaining genotypes composed the second group and had short fruits. These genotypes should not be considered distinct, because to do so, they should have at least two different levels of expression between them. However, when the fruit length of each genotype was measured, the clustering of means showed that 'Casca Dura Ikeda' had the longest fruit length and was significantly different from the other genotypes (Moreira, 2012).

RILs evaluated in this study were originally derived from crosses between accessions UENF 1381 and UENF 1421, and thus far, the selection made in the advanced generations of this bi-parental cross are considered to have several agronomic attributes and resistance to BS (Moreira, 2008; Riva-Souza et al., 2009; Moreira et al., 2009, 2010). Thus, the presence of different phenotypic expressions in the descriptors evaluated shows the variability of the RILs, even those aiming for selection for specific traits, as well as the efficiency of these descriptors in the differentiation of RILs.

Homogeneity is demonstrated by the variation in the expression of relevant traits in plants that comprise a cultivar, and when these plants are very similar, atypical plants are easily identified visually and the difference may occur only in one part of the plant, which should determine whether the plant is diverging from the standard of the cultivar (Brasil, 2011). Despite this recommendation, in the present study, we did not consider this point, i.e., any variation observed was quantified and reported.

Plants that could be considered to lie outside of the RIL or cultivar standard were not observed in 9 of the 22 descriptors evaluated. Two other descriptors identified a number of nonstandard plants below the limit defined for SNPC, resulting in 11 descriptors in which plants inside the lines were considered homogeneous (see Table 2).

The RILs with low numbers of heterogeneous descriptors were 1 ( 5 descriptors), 3 (7 descriptors), and 6 (8 descriptors). RILs 2, 5, 8, and 11 and 'Casca Dura Ikeda' showed heterogeneity for 9 descriptors. In this sense, the genotype used on a commercial scale in Brazil and registered at Ministério da Agricultura, Pecuária e Abastecimento has the same level of heterogeneity as that of the recombinant lines tested here. Heterogeneous lines for a smaller number of descriptors (RILs 1, 3, and 6) should be studied to obtain uniformity in the plants for a majority of descriptors. For the remaining lines, it should also occur; however, as the number of heterogeneous characters is greater, probably the desired level of homogeneity require more effort and dedication.

The degree of change in any genotype tested results from a combination of genetic and environmental components. The environmental influence varies with the type of expression of the characteristic, and for multicategorical characters, levels of variation due to environment are higher compared with those for binary characters. For the presence of capsaicin, 
the only binary descriptor used in this study, plants with different patterns within the same genotype were only registered to RIL 6. Segregation for capsaicin presence within this line has also been observed by Moreira et al. (2006). Pungency in C. annuum is conditioned by the $C$ gene located on chromosome 2 (Lippert et al., 1965; Blum et al., 2002). However, the amount of capsaicin is a quantitative trait influenced by environmental conditions, crop management, and maturation stage of the fruit (Wagner, 2003).

The genetic component of change is influenced by the propagation mode of the cultivar: little or no variation between plants is expected for autogamous plants or clonally propagated species within one line; in autogamous plants with some degree of crossfertilization, a slight variation in plants within the same line is tolerated (Brasil, 2011). Although $C$. annuum is considered a self-compatible autogamous species with hermaphrodite flowers, the rate of natural cross-pollination can occasionally reach $75 \%$. In addition, Faria Júnior et al. (2008) concluded that at least 10 species of insects visit pepper flowers and that insect pollination has a positive impact on the mass, diameter, pericarp thickness, and seed number of fruits produced. Thus, in addition to impairing the homogeneity of lines, the action of pollinators helps to increase the seed number in fruits originated through cross-pollination.

Notably, during the progression of the generations and experiments to evaluate genotype-environment interaction, the lines tested were cropped close to each other, possibly favoring outcrossing, which reinforces the need to evaluate the homogeneity of the genotypes at different stages of the breeding program. To avoid outcrossing, the flowers in every experiment should be protected before anthesis, and seeds for use in the next stages of the program should be removed only from the fruits of these flowers. Protecting flowers is a time-consuming job and requires very careful attention to ensure that the flower does not fall before or after fertilization.

Although phenotypic characterization has been effective in differentiating genotypes, the phenotypic descriptors do not offer total security in the analysis of the divergence between the lines owing to lack of polymorphism, environmental interference, dependence on the stage of plant development, and the type of character inheritance (Costa et al., 2009). In addition, it should be considered that the Capsicum RILs used in this study have the same genealogy (Becher et al., 2000; Priolli et al., 2002). To investigate more thoroughly the genetic heterogeneity among RILs, we used the information obtained in ISSR studies.

Eighty-two polymorphic and 8 monomorphic bands were observed during the analysis of the gels. The resolving power ranged from 1.0 [primers $\mathrm{VHV}(\mathrm{GT}) 7$ ] to 3.8 [primers (AG) 8YT, (AG) 8YC, and (AG) 7C], which are considered low compared to data obtained by Prevost and Wilkinson (1999), who obtained resolving power of 10.6 and 12.5 for 2 ISSR primers capable of distinguishing 34 potato cultivars.

The low genotype differentiation capacity of the primers used in our study may have occurred because the lines are closely related genotypes. However, Reddy et al. (2002) reported that the use of ISSR markers is a very efficient technique in distinguishing genotypes even though they are closely related. Thus, optimization of the conditions of DNA extraction, sample preparation, and amplification must be undertaken to obtain better results.

Cluster analysis using the UPGMA method, with a cut of $50 \%$, led to the formation of 5 groups (Figure 1). Group I was formed solely by RIL 1. Group II comprised RILs 6, 8, 11, and 13, 'Casca Dura Ikeda', and UENF 1381. The other groups were also formed by single RILs: group III corresponded to RIL 3, group IV to RIL 2, and group 5 to RIL 5. 


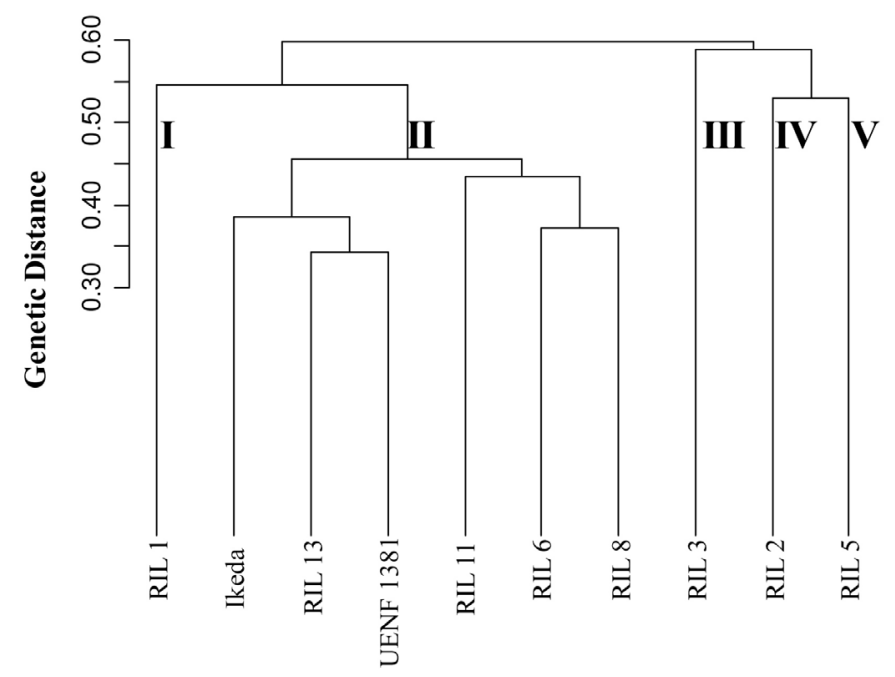

Figure 1. Dendrogram obtained with UPGMA from the Jaccard dissimilarity matrix of 8 Capsicum annuum recombinant inbred lines, the accession UENF 1381 and the cultivar 'Casca Dura Ikeda' (cophenetic correlation = 0.85).

Although we expected to achieve better differentiation among RILs using molecular analysis, only 4 of the 8 RILs $(1,2,3$, and 5) were clearly separated in isolated clusters with ISSR markers using the UPGMA method. In an assessment of genetic diversity of the Capsicum collection assembled by Costa et al. (2009), only with the combination of morphological data and molecular markers was it possible to completely distinguish the accessions tested and exclude the existence of duplicates. Giancola et al. (2002) observed that the best technique for differentiating soybean genotypes is the combination of simple sequence repeat markers and morphological descriptors. The same result was observed in the present study, because the molecular analysis had to be considered in conjunction with other descriptors to ensure proper identification of the genetic diversity of genotypes.

The cophenetic correlation coefficient was high (0.85), showing that the dendrogram reflects the dissimilarity matrix obtained by the arithmetic complement of Jaccard, demonstrating the consistency of clustering (Sokal and Rohlf, 1962). In the clustering by the Tocher method, there was also the formation of 5 groups, however, with some changes. The differences are in group I, which was formed by RIL 1, 8 and 13, in addition to cultivar 'Casca Dura Ikeda' and parent UENF 1381, and in group II, which was formed by the RILs 6 and 11. The other lines (RILs 2, 3 and 5) were individually clustered.

It is concluded that there are binary and multicategoric descriptors able to distinguish RILs that have the potential to be released as new cultivars. Among the descriptors suitable for such distinctions are leaf length, leaf pubescence, stigma position, fruit length, fruit diameter, predominant form in longitudinal and transversal fruit section, and reaction to BS. Some descriptors were heterogeneous in all genotypes; however, RILs 1, 3, and 6 were more homogeneous, and RILs 2, 5, 8, and 11 were heterogeneous for the same number of descriptors as that of the traditional cultivar 'Casca Dura Ikeda'. The clustering of the RILs based on molecular analysis allocated three RILs in isolated groups, contributing to the discrimination of the genotypes studied. 
Considering homogeneity level along with resistance to BS, RILs 1 and 6 are suitable for use as pre-cultivars in final tests to register and release 2 new C. annuиm cultivars. RILs 2 and 8 also have potential to be released as cultivars owing to their resistance to BS; however, the homogeneity of these RILs should first be achieved through new generations of controlled self-pollination.

\section{ACKNOWLEDGMENTS}

Research supported by Fundação Carlos Chagas Filho de Amparo à Pesquisa do Estado do Rio de Janeiro (Ph.D. scholarship to S.O. Moreira). We thank Professor Messias Gonzaga Pereira and Vitória Régia from UENF/Laboratório de Melhoramento Genético Vegetal for laboratory assistance.

\section{REFERENCES}

Becher SA, Steinmetz K, Weising K, Boury S, et al. (2000). Microsatellites for cultivar indentification in Pelargonium. Theor. Appl. Genet. 101: 643-651.

Blum E, Liu K, Mazourek M, Yoo EY, et al. (2002). Molecular mapping of the C locus for presence of pungency in Capsicum. Genome 45: 702-705.

Brasil (2006). Ato ${ }^{\circ} 2$ de 22 de Março de 2006. Instruções para Execução dos Ensaios de Distinguibilidade, Homogeneidade e Estabilidade de Cultivares de Pimentão e Pimenta (Capsicum spp.). Diário Oficial da República Federativa do Brasil, Brasília, 27 de Março de 2006, Seção 1. 7.

Brasil (2011). Proteção de Cultivares no Brasil. MAPA, Brasília.

Cook AA and Guevara YG (1984). Hypersensitivity in Capsicum chacoense to race 1 of the bacterial spot pathogen of pepper. Plant Dis. 68: 329-330.

Costa LV, Lopes R, Lopes MTG, Figueiredo AF, et al. (2009). Cross compatibility of domesticated hot pepper and cultivated sweet pepper. Crop Breed. Appl. Biotechnol. 9: 37-44.

Cruz CD (2006). Programa Genes: Análise Multivariada e Simulação. UFV, Viçosa.

Faria Junior LR, Bendini JN and Barreto LMR (2008). Eficiência polinizadora de Apis mellifera L. e polinização entomófila em pimentão variedade Cascadura Ikeda. Bragantia 67: 261-266.

Giancola S, Poltri SM, Lacaze P and Hopp HE (2002). Feasibility of integration of molecular markers and morphological descriptors in real case study of a plant variety protection system for soybean. Euphytica 127: 95-113.

Goulão L and Oliveira CM (2001). Molecular characterization of cultivars of apple (Malus x domestica Borkh.) using microsatellite (SSR and ISSR) markers. Euphytica 122: 81-89.

Hamza AA, Robène-Soustrade I, Jouen E, Gagnevin L, et al. (2010). Genetic and pathological diversity among Xanthomonas strains responsible for bacterial spot on tomato and pepper in the southwest Indian Ocean region. Plant Dis. 94: 993-999.

Jones JB, Minsavage GV, Roberts PD, Johnson RR, et al. (2002). A non-hypersensitive resistance in pepper to the bacterial spot pathogen is associated with two recessive genes. Phytopathology 92: 273-277.

Kwon YS, Lee JM, Yi GB, Yi SI, et al. (2005). Use of SSR markers to complement tests of distinctiveness, uniformity, and stability (DUS) of pepper (Capsicum annuum L.) varieties. Mol. Cells 19: 428-435.

Lee CJ, Yoo E, Shin J, Lee J, et al. (2005). Non-pungent Capsicum contains a deletion in the capsaicinoid synthetase gene, which allows early detection of pungency with SCAR markers. Mol. Cells 19: 262-267.

Lippert LF, Bergh BO and Smith PG (1965). Gene list for the pepper. J. Hered. 56: 30-34.

Marcuzzo LL, Fernandes JMC and Becker WF (2009). Influência da temperatura e da duração do molhamento foliar na severidade da mancha bacteriana do tomateiro. Summa Phytopathol. 35: 229-230.

Moreira GR, Caliman FRB, Silva DJH and Ribeiro CSC (2006). Espécies e variedades de pimenta. Inf. Agropec. 27: 16-29.

Moreira SO (2008). Reação à Mancha-Bacteriana e Desempenho Agronômico de Linhas Recombinadas de Capsicum annuит L. Master's thesis, UENF, Campos dos Goytacazes.

Moreira SO (2012). Caracterização Morfológica e Molecular de Pré-Cultivares de Capsicum annuum L. com Resistência à Mancha-Bacteriana. Doctoral thesis, UENF, Campos dos Goytacazes.

Moreira SO, Rodrigues R, Araújo ML, Araújo ML, et al. (2009). Desempenho agronômico de linhas endogâmicas 
recombinadas de pimenta em dois sistemas de cultivo. Ciênc. Rural 39: 1387-1393.

Moreira SO, Rodrigues R, Araújo ML, Riva-Souza EM, et al. (2010). Desempenho agronômico de linhas endogâmicas recombinadas de Capsicum annuum L. em sistema orgânico sob cultivo protegido. Ciênc. Agrotec. 34: 886-891.

Moura MCCL, Gonçalves LSA, Sudré CP, Rodrigues R, et al. (2010). Algoritmo de gower na estimativa da divergência genética em germoplasma de pimenta. Hortic. Bras. 28: 155-161.

Potnis N, Minsavage G, Smith JK, Hurlbert JC, et al. (2012). Avirulence proteins AvrBs7 from Xanthomonas gardneri and AvrBs1.1 from Xanthomonas euvesicatoria contribute to a novel gene-for-gene interaction in pepper. Mol. Plant Microbe Interact. 25: 307-320.

Prevost A and Wilkinson MJ (1999). A new system of comparing PCR primers applied to ISSR fingerprinting of potato cultivars. Theor. Appl. Genet. 98: 107-112.

Priolli RHG, Mendes-Junior CT, Arantes NE and Contel EPB (2002). Characterization of brazilian soybean cultivars using microsatellites markers. Genet. Mol. Biol. 25: 185-193.

R Development Core Team (2006). A Language and Environment for Statistical Computing. Vienna. R Foundation for Statistical Computing. Available at [www.r-project.org]. Accessed March 13, 2008.

Reddy MP, Sarla N and Siddiq EA (2002). Inter simple sequence repeat (ISSR) polymorphism and its application in plant breeding. Euphytica 128: 9-17.

Riva-Souza EM (2006). Uso dos Métodos Genealógico e "Single Seed Descent" (SSD) para Obtenção de Linhas de Pimentão Resistentes à Mancha-Bacteriana. Doctoral thesis, Universidade Estadual do Norte Fluminense Darcy Ribeiro, Campos dos Goytacazes.

Riva-Souza EM, Rodrigues R, Pereira MG, Sudré CP, et al. (2004). Inheritance of bacterial spot disease in Capsicum annuum L. Crop Breed. Appl. Biotechnol. 4: 490-494.

Riva-Souza EM, Rodrigues R, Sudré CP, Pereira MG, et al. (2009). Genetic parameters and selection for resistance to bacterial spot in recombinant $\mathrm{F}_{6}$ lines of Capsicum annuum. Crop Breed. Appl. Biotechnol. 9: 108-115.

Shen J, Ding X, Liu D, Ding G, et al. (2006). Intersimple sequence repeats (ISSR) molecular fingerprinting markers for authenticating populations of Dendrobrium officinale Kimura et Migo. Biol. Pharmaceut. Bull. 29: 420-422.

Sokal RR and Rohlf FJ (1962). The comparison of dendrograms by objective methods. Taxon 11: 30-40.

Sowell G Jr (1960). Bacterial spot resistance of introduced peppers. Plant Dis. Rep. 44: 587-590.

Sudré CP, Goncalves LS, Rodrigues R, do Amaral Junior AT, et al. (2010). Genetic variability in domesticated Capsicum spp as assessed by morphological and agronomic data in mixed statistical analysis. Genet. Mol. Res. 9: 283-294.

Wagner CM (2003). Variabilidade e Base Genética da Pungência e de Caracteres do Fruto: Implicações no Melhoramento Numa População de Capsicum annuum L. Doctoral thesis, ESALQ/USP, Piracicaba. 